\title{
AN ELECTIVE AFFINITY: CAMUS` TRANSLATIONS OF LOPE AND CALDERÓN
}

For a period of about ten years after the presentation of his own play Les Justes, in 1949. Camus' main contact with the theater was not as a playwright but as adapter and translator. During this period he adapted and recasted Pierre de Larivey's Les Esprits, originally transposed in 1940 but further revised in 1953, Dino Buzzati's An Interesting Case, William Faulkner`s Requiem for a Nun, and Dostoyevsky's The Possessed. Camus also translated and adapted two plays from the Spanish Siglo de Oro: Calderón's La Devoción de la cruz and Lope de Vega's El Caballero de Olmedo.

Many were those who wondered why did Camus devote so much time and energy to as seemingly futile a task as the adaptation of the works of others. Perhaps no other action caused more surprise and perplexity among his critics and supporters than his decision to translate, adapt, and stage the two Spanish plays, in all appearances so antipodal to Camus' philosophy. And indeed at first glance the apparent philosophical differences that separate the French author from the two Spanish playwrights make Camus choice difficult to justify. But are these differences as acute as commonly claimed? Was Camus' task as fruitless as many believed? A study of the circumstances surrounding his translation of these two plays and an analysis of the respective philosophies and beliefs of the three authors reveal some answers to these questions.

Although not an active and vehement anti-Christian campaigner, Camus often found himself attacking religious ideas that he could not accept. He was not a blind and bitter opponent who engaged in a total negation of the principles of the Church but rather a moralist whose concept of life differed markedly from the religious one. It is therefore surprising that he should have translated La Devoción de la cruz, a play which glorifies a style of life against which he wrote many pages. What reasons could have prompted Camus, a fervent agnostic, to join hands with a Catholic playwright to exalt the saving power of the cross? How can one reconcile his thesis that hope in the after-life is a certain means of negating the present existence with his translation and adaptation of a religious play? Even though constructive paradoxes abound in his essays, how can one accept the apparent contradiction that results from the juxtaposition of two texts as seemingly antagonistic as Le Mythe de Sisyphe and Calderón's play? Finally, how can we not be surprised to find alongside Sisyphus, the doomed but happy rebel whose eternal futile and monotonous task symbolizes the dignified confrontation with life's absurdity, Eusebio, the protagonist of Calderón's play, a man whose main goal in life is to receive God's grace, and Don Alonso, Lope de Vega's melancholic and virtuous lover "cabellero de Olmedo".

Camus" decision to translate La Devoción de la cruz, it should be stated in his defense, was not totally his own. He undertook this task at Marcel 
Herrand's request. Camus, however, would not have accepted such an undertaking had the play been offensive to him or its teachings diametrically opposed to his. Furthermore, the fact that he chose to translate Lope de Vega's El Caballero de Olmedo, a play of the same period and consequently immersed in the religious ardor of the times, would seem to rule out chance. His choice of these two plays was dictated by personal as well as artistic reasons.

Camus version of these two Spanish plays, indeed of all his adaptations and translations, should not be viewed as a hiatus in his literary career. They were too important to him personally and to his long-range plans for the theater not to deserve greater merit and study.

Let us recall that, as Roger Quilliot rightly writes, "le théàtre avait été ... pour Camus à la fois une passion et une sorte de vacance". ${ }^{1}$ When asked in a televised interview in 1959, "Pourquoi je fais du thèàtre" he simply and pointedly replied: "tout simplement parce qu une scène de théàtre est un des lieux du monde où je suis heureux" (Thêâtre, p. 1718). To further justify his passion for the theater he added: "pour moi le thêâtre est justement le plus haut des genres littéraires et en tout cas le plus universel" (Thêatre, p. 1724). At a time when his creative energies were occupied elsewhere, when he was undergoing a moral crisis, his translations and adaptations afforded him a chance to immerse himself, as "metteur en scène," in the world he loved. In an attempt to justify all his efforts in the area of theater and to silence his critics, Camus categorically stated: "je me sens si peu diminué par ce travail, que je continuerai tranquillement à le faire, autant que j’en aurai la chance" (Théâtre, p. 1785).

His attachment to the stage, however, was also altruistic. He was driven by a desire to effect a renaissance of the French theater. In a conference given in Athens in 1955. Camus expressed his optimism concerning the future of the theatre. Since the reform initiated by Jacques Copeau, he said, playwrights, rather than exploiters and industrialists of the stage, were engaged "à remettre l'art dramatique à sa vraie place, au sommet des arts littéraires" (Théatre, p. 1703). We know that Camus was too committed to the theater to avoid participating in this reform, which seemed all the more exciting because all the conditions that foster the creation of true tragedy were clearly present in his own time. He saw definite parallels between the conditions that ushered in the tragedy in two previous eras - the Greek classical and the Elizabethan - and our modern era (Théatre, p. 1702). All three he considered periods of transition, not without past glories but heavy with disrupting menaces: in each period, the past had belied what were considered irrefutable truths, the present was dramatic and unstable, and the future did not promise to replace the absolute principles that had been destroyed. During these periods, man was a tragic figure because "consciemment ou non [il] se détache d'une forme ancienne de civilisation et se trouve devant elle en état de rupture sans, pour autant, avoir trouvé une nouvelle forme qui le satisfasse" (Théatre, p. 1703). The theater should 
present the tragic image of man during a period of transition, but, according to Camus, this image had proven elusive. He believed, however, that encouraging glimpses had been captured by Gide, Montherland, Giraudoux, Claudel, and others.

There is no doubt that one of his greatest ambitions was to be classed among these authors, who were attempting to turn the theater into the faithful reflection of a tragic era. He did help to define the new direction envisioned for the dramatic arts. Influenced by Antonin Artaud's ideas, he tried to give life to many of the concepts found in Le Théatre et son double. ${ }^{2}$ The result was his play L'Etat de siege, in which we note a conscious effort to give a new dimension to the theater, to incorporate all the possible means of communication in order to transform it into a complete spectacle.

$L^{\prime}$ 'Etat de siege was a complete failure. Had Camus followed the precepts he advocated in the aforementioned conference, the result of his play might have been less disappointing. L'Etat de siege lacks the tragic dimensions he required of all tragedies. There is no tragedy in it because there is no dramatic confrontation. The fundamental ingredient of tragedy, according to Camus, is a clash between two forces, both of which can be considered just or at least justifiable. In Camus' play this equilibrium is broken by having the just rebel against the unjust. The play is deprived not only of the tragic element but also of suspense since the characters are too easily identified with good or evil: the Plague and his secretary embody crime and unjust punishment so that their cause can arouse no sympathy, and Diego is the noble defender of freedom, the paragon of "l'homme révolté."

Perhaps the failure of $L^{\prime}$ Etat de siège can be attributed to the form as well as to the content. Raymond Gay-Crossier has shown that Camus followed very closely the structure of the Spanish autos sacramentales, religious plays whose purpose was to educate the masses about the significance of Church dogmas presenting biblical or theological subjects. ${ }^{3}$ If Camus' intention was to write a lay auto he was forfeiting his opportunity to compose a tragedy since, by his own definition, an auto sacramental is "un spectacle où la vérité unique est solennellement proclamée" and thus is devoid of the necessary clash of "justifiable forces." (Theâtre, p. 1706). With the pamphletary style and the structure of a religious drama, $L^{\prime}$ Etat de siège seemed more destined to play a didactic role than to renew the modern theater.

His search for a means to infuse new blood and energy into French theater made him turn to Spain. This decision was quite natural. That Camus, whose mother was Spanish, felt deep ties with Spain, its people, and its cultural heritage is undeniable. Madariaga, echoing many of his compatriots, pointed out that Camus "sentait les choses d'Espagne non seulement par l'esprit mais par le coeur et la chair. "4 Camus' own words and character add credence to this statement. Although initially he tried to suppress and control his strong Spanish pride, which he refers to as his "castillanerie" in his preface to "L'Envers et l'Endroit," he finally accepted and even emphasized it, referring in many of his speeches to his Spanish ancestry. In his 
preface to $L$ 'Espagne libre, for instance, he declared: "Par le sang. l'Espagne est ma seconde patrie." In a speech given to "les Amitiés méditerranéennes" in 1938 and later published in 1958, he recognized not only his ties with Spain but his debt to it: "Amis espagnols ... j'ai envers votre patrie, sa littérature et son peuple, sa tradition, une dette qui ne s'éteindra pas" (Essais, p. 1907).

What Camus' attitude and words suggest is that his enthusiasm for the land and affection for its people naturally inclined him to look to Spain for inspiration and to pay it tribute by making Spain's Siglo de Oro more accessible and more relevant to French audiences. As influential as these personal reasons may have been, however, his decision to translate these two Spanish plays was in all probability ultimately dictated by artistic concerns.

His accepting to translate Calderón's play and more significantly his own desire to provide a French version for Lope de Vega's El Caballero de Olmedo responded to a long-range plan to come into closer contact with the drama of the Spanish Golden Age, and to inject new life into French theater. This he made quite clear in the introduction to his translation of Lope's play: "Dans notre Europe de cendres, Lope de Vega et le théâtre espagnol peuvent apporter aujourd'hui leur inépuisable lumière, leur insolite jeunesse, nous aider à retrouver sur nos scènes l'esprit de grandeur pour servir enfin l'avenir véritable de notre théâtre" (Théâtre, p. 718). Both $L a$ Dévotion à la croix and Le Chevalier d'Olmedo produced at the Angers festival of 1953 and 1957 were widely acclaimed and lauded as the theatrical successes of their respective seasons. In choosing the two Spanish plays Camussatisfied his pressing need not to lose touch with the stage. to come into closer contact with authors he admired, and to cast about for new paths to follow in his heartfelt desire to revitalize France's national theater.

An important question. however, still remains unanswered. Why, not being a believer, did Camus accept to translate La Devocion de la cruz, a religious play"? This is what he replied when pressed on this issue: "Parce que son héros a une foi qui. pour le sauver, exige l'action "s Surprisingly enough Camus was not perturbed at all by what appeared to many as a denial of his earlier opinions. He did not see any serious contradiction because he discovered in Lope de Vega and Calderón de la Barca enough common denominators and parallels with his own work to more than offset whatever differences existed. Both the similarities and the differences become apparent if we compare the respective philosophies of the three authors.

Like Camus' characters, Julia, the female protagonist of La Devocion de la cruz is quite conscious of her personal freedom. This parallel has not passed unnoticed to critics. "They often mention the word "libertad" to which Calderón's Julia seems to attribute a meaning analogous to "liberté" in the Camusian sense. ${ }^{6}$ Left unexplained, however, this comparison can be detrimental to the understanding of Camus' thought since, in spite of what is common in the concepts expressed by these two words, there are numerous 
aspects that distinguish them.

For Camus there is no "liberte"" without consciousness of the absurd. In fact, it is the natural result of this awareness: "Je tire ainsi de l'absurde trois conséquences, qui sont ma révolte, ma liberté, et ma passion" (Essais, p. 145). Man becomes free when he accepts the true nature of death: “. . . . il n'y a pas de lendemain. Voici désormais la raison de ma liberté profonde" (Essais, p. 141). Before man's awareness that there is no metaphysical sense to life, he may act as a free man, but it only takes the realization of the absurdity of death to shake his convictions. What he had considered freedom is nothing else than adherence to principles, goals, and obligations. The vision of death detaches him from these principles which he considered absolutes. It is only then that he is truly free, but it is a freedom that does not liberate him: he becomes completely responsible for his own life; he is to carry this heavy burden alone.

Acceptance of this type of freedorn implies submission to a particular style of life. Because there is no tomorrow, man must savor every moment in its passing; always conscious, he must collect a succession of present moments; not being bound by absolute principles or morals, he need not make any choices, which, in a way, already implies a choice. "Tout est permis," however, is not the joyful slogan of one who senses his complete liberation but the desolate cry of the man who has realized his immense responsibility: no absolute truths will assist him in his personal decisions; he is the sole author of his life.

For Calderón, having Julia speak of her "libertad" is but another means of enhancing the benevolent nature of God. The confrontation between Julia and Curcio opposes a Christian dogma to the sentiment of honor so as thoroughly to disgrace the latter. Menéndez Pelayo explains that in the sixteenth-century, the patriarchal authority was supreme and that "imperaba el llamado sentimiento de honor, que viene a ser una moral social relativa, debajo de la moral cristiana, y a veces contra ella, moral relativa que se impone en las costumbres tiránicas e inflexiblemente, hasta en los que más la niegan y contradicen."7 To save the family honor which he believes blemished by the love berween Julia and Eusebio, Curcio decides to impose the religious life on his daughter. Submission to this code of honor is so blind that it even encroaches on the God-given rights of the individual. Julia considers her freedom of choice to be independent of filial obedience because it is a divine gift: but to her father nothing is sacred, everything can be sacrificed at the altar of his despotic ruler, honor.

The differences between Camus " "liberté" and Julia's "libertad" are thus significant. "Je ne puis comprendre ce que peut être une liberté qui me serait donnée par un être supérieur" (Essais, p. 140) affirms the former; for Julia, freedom is a gift from God: "la libertad que me dio/el cielo es la que te niego" she declares to her father. "In Julia's argument, "libertad" and "libre albedrio" are synonyms. Since free will signifies man's freedom to cooperate with God for his personal salvation, we can interpret Julia's opposition 
to her father's plans in a religious way: she cannot accept life in a convent as the best means of working for her salvation. Needless to say, none of the conclusions drawn from "liberté" apply to the strict interpretation of free will.

In Calderón's world man's only responsibility seems to be obedience to God's will. Free will, then, would be equivalent to the "will" or choice to obey divine law. In Camus' world, on the contrary, in the absense of universal and divine laws to which man must aspire, man's responsibility is to create his own. If the two respective concepts of freedom have a point of contact it is to be found by dissociating Calderón from Julia's words. It is evident that for the playwright the salient aspect of this problem is the opposition between two fathers: God, out of his limitless love, gives complete freedom to his children; Curcio, guided by egotistic and mundane laws, tyrannically suppresses this divine gift. But for Julia the situation does not primarily concern metaphysical preoccupations. She loves Eusebio but her father is determined to make this love impossible. Out of desperation she calls to her aid the one human right that is not subject to her father's rule. In this respect, her "libertad" could be equated to Camus': "La seule que je connaisse, c'est la liberté d'esprit et d'action" (Essais, p. 140), especially since she demands "liberté d'action" in the name of free will.

Another similarity that is often mentioned is the relation of the murderous behavior of Caligula to that of the main characters in La Dévoción de la cruz, particularly Julia, whose crimes are strikingly gratuitous.

Let us recall that Caligula's atrocious acts may seem without motive but are in fact governed by the logic of the absurd man. Drusilla's death awakens him to the realization that life has no meaning. This noble prince who, in the words of Scipio, "voulait être un homme juste" and who believed that "faire souffrir était la seule façon de se tromper" (Théâtre, p. 19 ) is no different from the modern man whose existence is the product of habit. Both accept life as it is without question. As a result of this death. Caligula understands the absurdity of life and discovers his complete freedom which he uses and abuses whimsically.

Camus had written that since "toutes les expériences sont indifférentes . . . on peut être vertueux par caprice" (Essais, p. 150): Caligula becomes destructive for the same reason. Caligula's character is masterfully and logically drawn: he represents the absurd man who chooses to exploit his complete freedom to the limit by destroying man and eradicating his beliefs.

Such logic of character cannot be found in Julia. Her murderous behavior should be considered primarily as carelessness on the part of the author. There is no coherence, no preparation to support a radical change in her conduct. As has been often pointed out, most notably and incisively by Menéndez Pelayo, Julia's crimes fail to shock as they are intended because they are not credible. ${ }^{9}$ Unlike Camus whose philosophy did not ostensibly interfere with the logical development of Caligula's character, Calderón's overt wishes to turn Julia into a sinner unworthy of redemption so as to 
accentuate her ultimate apotheosis seriously weakened the credibility of her personality. No possible motive or excuse can be found to justify her sudden criminal acts.

As Camus stated, Caligula demonstrates that "on ne peut tout détruire sans se détruire soi-même" (Théâtre, p. 1729). With a mastery that he failed to attain in any of his other plays, he used his characters here to illustrate his philosophy without dehumanizing them, without turning them into symbols or allegorical figures lacking human warmth and truth. This is precisely the main difference between Caligula and Julia: the former gives life to Camus' ideas as he naturally develops his personality, the latter acts contrary to what is expected from her to give the necessary strength to Calderón's religious ideas.

There are, however, certain notable similarities. Their metamorphosis from peaceful, benevolent individuals to cold-blooded murderers is drastic and sudden. In both cases it is possible to identify the incident that provokes the monstrous behavior: Caligula turns into a cynical, demoniacal tyrant after Drusilla's death; Julia commits her crimes after feeling betrayed and abandoned by God and Eusebio. Both discover a freedom which they interpret as a license to destroy. ${ }^{10}$

Camus' interest in Calderón's play could be explained quite easily be seeing in him, as many have, a latent Christian whose obstinate search for answers predisposed him to eventual faith in God. Camus' search for explanations for suffering and injustice as well as his refusal to accept God's supremacy in metaphysical questions need not be interpreted as a desire to believe in God. And neither should such significance be associated to his having translated this religious play.

For Camus, La Devoción de la cruz was relevant in our age not so much for its theological teachings as for its modern meaning. Let us recall that when a reporter asked him why he had translated this play, he answered "Parce que son héros, a une foi qui, pour le sauver, exige l'action." For him, Eusebio's outstanding trait is his zeal, his active desire to obtain salvation. We must admit that his interpretation does not follow orthodox lines since Eusebio's actions often seem more appropriate to attract God's ire than divine grace. But even Calderón does not neglect to demonstrate his hero's contribution to his own salvation. Even though Eusebio has convincing evidence that he has received grace, he turns it into efficacious grace through his personal efforts: he gains assurance from Lisardo and Alberto that he will not die without confession; he proves his perfect love of the cross by rejecting the one earthly pleasure that he had feverishly sought; and he spares his father's life. For Camus, Eusebio's active participation in his own salvation is important because religion, like the notion of absurdity, can induce passive behavior. In Camus' reading of the play, then, grace is translated into action. Calderón's characters, like his own, choose action over passivity.

In the introduction of La Dévotion à la croix, Camus explains the 
message of the play in the following manner: "c"est plus de trois siècles avant Bernanos que Calderón prononça et illustra de façon provocante. dans La Dévotion, le 'Tout est grâce' qui tente de répondre dans la conscience moderne au 'Rien n'est juste' des incroyants" (Théatre, p. 525). In what ways can these two seemingly opposed concepts be equated? The "Tout est grâce" describes a world under the divine guidance of a benevolent God: everything that occurs has its logical place in the natural development of His scheme where, to use Alexander Pope"s celebrated verses, "All Discord, Harmony not understood,/ All partial Evil, universal Good." To the unbelievers, "Rien n'est juste" responds more accurately to their vision of a world where injustice is capriciously favored by chance. The common denominator to these two fornules, however, is that they negate personal effort, since no action can change the unchangeable. Many, however, act out of humility and devotion; others out of rebellion. But in both cases they battle passivity with action, and continual action is what Camus admired and advocated in the face of absurdity.

If Camus' translation of La Devoción de la cruz owes much to Marcel Herrand's request, the decision to transpose Lope de Vega's El caballero de Olmedo was totally his own. It responded, as has been mentioned earlier, to a long-range plan to rejuvenate French theater and to come into closer contact with the literature to which he felt indebted (see Essais, p. 1923). But most of all his decision represented a definite preference for the world depicted by Lope de Vega, a familiar world with which Camus could easily identify himself.

In "Entre oui et non," a young Camus cries out his indignation against man's obfuscation of simple questions: "Oui, tout est simple. Ce sont les hommes qui compliquent les choses" (Essais, p. 30). Later, in Le Mythe de Sisyphe he offers direct and simple answers to sorne seemingly complex questions. What is the metaphysical meaning of life? There is none, he claims. Life is only meaningful in human terms. Does the absense of meaning justify suicide? On the contrary, life "sera d'autant mieux vécue qu'elle n'aura pas de sens" (Essais, p. 138). The young in his native Algeria live as if they had discovered these basic truths. A subconscious discovery, no doubt, imparted by the Mediterranean whose irresistible invitation to live nullifies man's transcendental preoccupations: "si le langage de ces pays [on the Mediterranean] s'accordait à ce qui résonnait profondément en moi. ce n’est pas parce qu“il répondait à mes questions, mais parce qu'il les rendait inutiles" (Essais, p. 44). In Lope`s drama, these questions are also vain. There is no time for his heroes to engage in introspective analysis or in questioning the meaning of life: all their concentration is joyfully dedicated to exhausting the possibilities of the present. Baret, an earlier translater of Lope de Vega's works, enthusiastically praises their passion for life:

... [ils] raisonnent peu: mais comme ils agissent! Ils ne se replient point sur eux-mémes pour analyser leurs sentiments; ils oublient de se regarder vivre. mais comme ils sont vivants! Dans ces drames voluptueux, on sent des hommes heureux de vivre sous un beau ciel, de jouir de ces 
nuits embaumées par les parfums qui inondent au mois de mai la Vega de Valenoe et les jardins de Séville. Toujours sous l'influence despotique d'un sentiment déterminé, ils ont hâte de le satisfaire."

Camus naturally understood this "hurry" to satisfy a passion. In "L'Eté à Alger" he states that "le signe de la jeunesse . . . c'est une précipitation à vivre qui touche au gaspillage," and then adds that "la vie prend la courbe des grandes passions, soudaines, exigeantes, généreuses. Elle n'est pas à construire mais à brûler" (Essais, p. 72). He speaks of the youths of Belcourt, Alger, or Bab-el-Oued, but how perfectly his words apply to the lovers of Olmedo!

Only the energy of youth keeps life "burning" brightly. Fabia encourages Ines and Leonor to take full advantage of the best years of their lives, because, as she declares philosophically, only two things improve with age:

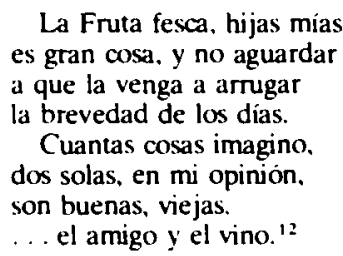

The same idea is developed more passionately in "L'Eté à Alger," where Camus, inebriated with his own youth and with nature's exhilarating invitation to exhaust the present, observes that men "trouvent ici pendant toute leur jeunesse une vie à la mesure de leur beauté. Et puis après, c'est la descente et l'oubli" (Essais, p. 68).

One of the leit-motifs in Camus' work is the search for a pure and honest form of communication. It is surprising that a man who was so close to words should mistrust them, but he accuses language of often serving human hypocrisy, of complicating the simple and obfuscating the clear. ${ }^{13}$ For him, the ideal form of expression approaches silerrce. This theme is found in L'Etranger, whose hero is remarkably taciturn, and also in "Entre oui et non," where Camus recalls a visit with his mother. They face each other in silence and then he asks her if the lack of conversation bores her. His mother answers that he has never spoken very much and Camus explains: "C"était vrai, il ne lui a jamais parlé. Mais quel besoin, en réalité? A se taire, la situation s'éclaircit. Il est son fils, elle est sa mère. Elle peut lui dire: 'Tu sais"' (Essais, p. 29). Only two words are needed to affirm that communication exists. In La Peste we find still another example of the wordless understanding of hearts. Grand, thinking about the breakdown of his marriage, recalls: "Tant que nous nous sommes aimés, nous nous sommes compris sans paroles" (Théâtre, p. 1286).

The examples of unspoken understanding are abundant in Camus' work. Even his translation provides further evidence that a person's eyes rather than his words can best convey the messages of the heart, there is something 
ethereal, crystalline and highly conductive in the eyes that best serves as the medium for the communication of noble sentiments. In Le Chevalier d'Olmedo, we can follow with emotion the silent exchange of eloquent glances between Ines and Alonso. Without having spoken a word to each other, they know that they are in love. Alonso describes their visual exchange this way:

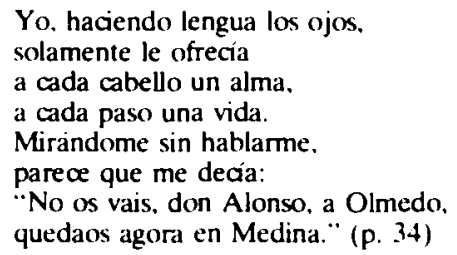

In religious terms, action is better than passive faith. In secular terms, action is better than words. In both instances, the emphasis is placed on willed activity.

Another interesting similarity results from comparing the morality of a gentleman in sixteenth-century Spain and the "code de la rue" of the young men in Algeria. Camus enumerates the simple rules of conduct: "On ne 'manque' pas à sa mère. On fait respecter sa femme dans les rues. On a des égards pour la femme enceinte. On ne tombe pas à deux sur un adversaire, parce que "ça fait vilain'" (Essais, p. 72). He who fails to respect this simple set of rules "is not a man." The importance attributed to "being a man" can be deduced from Céleste"s answer during Meursault's trial: "On lui a demandé . . . ce qu il pensait de moi et il a répondu que j'étais un homme" (Théatre, p. 1191). Céleste describes his friend with the most laudatory remark that comes to his mind and finds it impossible to elaborate upon what to him is self explanatory. He lacks the eloquence to expound on the connotative significance of this simple attribute which easily encompasses within its bounderies qualities like righteousness, integrity, and loyalty.

Don Alonso also believes in simple points of ethics. Having saved the life of his adversary, he cannot take seriously the warnings that Don Rodrigo still wishes him wrong. His noble deed can only be repaid with the confirmation of a new friendship, not with the hate of an enemy:

\footnotetext{
ya no puede ser

que don Rodrigo me envidie, pues hoy la vida me debe: que esta deuda no permite que un caballero tan noble en ningún tiempo la olvide. ... la ingraxitud no vive en buena sangre, que siempre entre villanos reside.

En fin, es la quinta esencia de cuantas acciones viles tiene la bajeza humana. pagar mal quien bien recibe. (p. 105)
} 
Don Alonso's argument is based on his faith in man's honor. His rival's jealousy and envy will naturally turn to friendship due to an unforgettable debt. The morality of the nobility here is not really different from the "code de la rue." One underlines the intrinsic goodness of men of "buena sangre," the other emphasizes the importance of "being a man": both consider sacrilegious the blemishing of man's honor.

To provide a model for our times, Camus turned the central figure of an ancient myth into the image of modern man accepting, completely unaided, the entire load of his absurd life. Lope's drama also idealizes a type of individual whose exemplary behavior inspired the men of his time. Don Alonso may lack the psychological depth, the complexity of character that we require of our heroes. His perfection, his almost superhuman qualities would be judged trite in our cynical age. but then, a hero like Sisyphus would hardly have stimulated the spirit of a Spaniard living in the sixteenth century. Each era calls for and creates the heroes it needs. Camus gave us a hero who paradoxically enjoys performing an absurd and repetitive task: Lope preferred to present a paragon of human virtues. But Lope's protagonists. as well as Calderon's, are committed to what they do and believe. And we know how much Camus valued commitment.

Camus' adaptations and translations owe their existence to his continual search for happiness and his uncompromising desire to extract the full richness from the "now," and his happiest moments, as he often confessed, were generally related to the theater. He loved to rehearse feverishly with a team of actors: he enjoyed the feeling of cooperation and comradeship that flourished during the preparation of a play; he longed for this nucleus of human solidarity and friendship that warmed his sensitive heart. These activities replenished his vitality and allowed him to face the less pleasant tasks of his work, to fight more vigorously for the many causes he espoused. In spite of the many accusations to this effect there was no betrayal to his principles and his followers in his devotion to the theater: he was truthful to himself and others. "Je ne veux pas me résoudre à choisir,." he wrote in "La Mort dans l'âme". and he remained faithful to this resolution (Essais, p. 39).

When other activities were demanding his time, adaptations and translations proved a convenient way of keeping in touch with this source of joy and energy by practicing his favorite genre. To regard his translations as mere enjoyment, however, would be to wrong Camus' sense of duty. His choice of the two Spanish plays was not fortuitous. On the one hand they reveal an extremely capable and sensitive translator and "homme de théâtre." On the other they contribute to the understanding of Camus' mission to reform French theater along the lines established by Artaud and to make it reflect more faithfully the tragedy of modern man. Camus succeeded brilliantly in the former: his presentation of these two plays were hailed as complete successes, as near perfect illustrations of Artaud's concept of total theater. In the latter he faced greater obstacles as he attempted, in spite of many and obvious differences, to make the protagonists of La Dévotion a 
la croix and Le Chevalier d'Olmedo congruent with his philosophy, to turn them into heroes of the absurd by accentuating and emphasizing their individualism, their spiritual grandeur, their almost obsessive passion for life, and, above all, their personal action in determining their own fate. Rather than a hiatus in his literary career and philosophical development, rather than excursions into seemingly opposite and unfertile areas of thought, these two translations, although not the direct result of Camus creative genius, represent a significant aspect of his literary production. ${ }^{14}$

Universing of Michigan

MANUEL A. HSTHBAN

Notes

1. Albern Camus, Théatre, Recits, Nouvelles, ed. Roger Quilliot (Paris: Editions Gallimard: Bibliothèque de la Pléiade. 1967).p. 1846. Subsequent references to this edition will appear in the text as Theätre. References to his Essais, ed. Roger Quilliot (Bruges: Gallimard, 1967), will also appear in the text as Essais.

2. Raymond Gay-Crosier, Les env'ers d'un echec (Paris: Bibliothèque des Lettres Modernes, 1967), pp. 134-136. Among the many parallels between the ideas in Le Théatre et son double and Camus' play, it is interesting to note this summary given by Gay-Crosier: " $L$ 'Etat de siege s'efforce d'actualiser méthodiquement plusieurs élèments que le manifeste du 'theátre de la cruauté' propose au lecteur, notamment 'la bataille de symboles', le spectacle qui 'pousse à une sorte de révolte virtuelle'. 'l'attitude héroïque et difficile'."

3. Gay-Crosier. pp. 155-158.

4. Salvador de Madariaga. "Un des nótres," Preuves, no. 110 (April. 1960). p. 13.

5. Vicente Marrero, "La seconde patrie de Camus." Table Ronde, no. 146 (February, 1960), p. 151, citing Camus' answer to a question by López Sancho for the magazine $A B C$.

6. This parallel is passed from critic to critic without ever being explained. John Philip Couch refers to it in his article "Camus" Dramatic Adaptations and Translations," French Revien; vol. 33, no. 1 (October, 1959), p. 31; Manuel Durán quotes Couch in his article "Camus and the Spanish Theater," Yale French Srudies, no. 25 (Spring, 1960), p. 129, adding only his endorsement; and finally, we find the same companson in Ilona Cooms' book Camus: homme de theatre (Paris: Gigel, 1968), p. 152.

7. Marcelino Menéndez Pelayo, Estudios y' discursos de critica historica y literaria (Santander: Edición Nacional de las obras completas de Menéndez Pelayo, 1941), tome III, p. 118.

8. Pedro Calderón de la Barca, La Devocion de la criz (fifth edition; Zaragoza: Editorial Ebro. 1968), p. 56.

9. Menendez Pelayo, p. 199

10. In his article Couch argues that Pelayo's criticism of Julia's character could be directly applicable to Caligula. We cannot agree with this judgment. If it is true that Julia's five or six homicides are incomprehensible because of their motiveless nature, the same cannot be said about Caligula's atrocities. All the crimes performed by the Roman emperor are governed hy an overriding motive - achievement of the impossible - and conform perfectly with the logic of the absurd man. xxvi.

12. Lope de Vega, El Caballero de Olmedo (eight edition; Zaragoza: Editonal Ebro, 1966), p. 40. All subsequent references to this edition will appear in the text.

1.3. It is man who complicates things by misusing words: "Oui, tout est simple. Ce sont les hommes qui compliquent les choses. Qu' on ne nous raconte pas d'histoires. Qu' on ne nous dise pas du condamnè à mort: "Il va payer sa dettè à la société". mais: 'On va lui couper le cou. 'Ca n'a pas l'air de rien. Mais ça fait une petite différence" (Essais. p. 30).

14. The subject for this paper was suggested to me by my brother. Julio Esteban. who did some of the initial research. 